\title{
IMPACT OF TOTAL QUALITY MANAGEMENT PRACTICE ON CUSTOMER RETENTION AND SATISFACTION
}

\author{
Abdul Hakim Noori \\ Department of Management, Vivekananda Global University, Jaipur, India
}

\begin{abstract}
Total quality management practice is a strategy of business-wide management to consistently increase the quality of products/services/processes by focusing on the needs and desires of consumers to improve customer engagement, loyalty and company performance. The relationship between overall quality control strategies and client retention, loyalty and efficiency is mixed. Total quality management is a firm-wide management methodology for the constant enhancement of products/services/processes quality with an emphasis on customer demands and preferences. This paper aims at exploring and recognizing the effect on consumers' retention and loyalty of full-fledged quality management activities, different methods of total quality. In order for a competitive edge to emerge and to boost corporate efficiency and customer loyalty an increasing number of companies use absolute quality control as a strategic basis. As a consequence of intensive global competition, the idea of total quality management was created. The concepts of total quality management, processes, tools and strategies are given significant importance by international trading and competitive competition organisations.
\end{abstract}

Key words: Total quality management, Customer retention. Customer satisfaction, Loyalty, Efficiency.

Cite this Article: Abdul Hakim Noori, Impact of Total Quality Management Practice on Customer Retention and Satisfaction, International Journal of Management, 11(12), 2020, pp. 2613-2618.

http://iaeme.com/Home/issue/IJM?Volume=11\&Issue $=12$

\section{INTRODUCTION}

Total quality management approach is an overarching organisational management strategy of constantly enhancing product/service/process efficiency by concentrating on the needs and desires of consumers in order to improve engagement, loyalty and business efficiency. The partnership between overall quality control activities and retention, loyalty and efficiency of the consumers has mixed outcomes. This research would therefore analyse the impacts on consumer retention and loyalty of complete quality control activities. 
The principles and methods of total quality management (TQM) are now recognised as part of almost every manager's "toolkit." Powel (1995) notes that most major corporations have taken on TQM somewhere and official award for consistency is a tribute to whether they work in Japan, the United States, Europe or Australia. Implementing TQM is a big organisational shift which calls for a change in the culture, procedures, strategic goals and beliefs of the organisation.

A growing number of organizations use total quality management as a strategic foundation for generating a competitive advantage and improving firm performance and customer retention and satisfaction. Firms that have won quality awards generally outperform other firms with respect to income measures, customer loyalty and stock market value. It is no surprise that the links among market orientation, total quality practices, and performance have attracted the attention of marketing and operations management researchers' alike

\section{OBJECTIVES OF THE STUDY}

The aims of this study are as follows:

1. To research the effect on TQM on customer retention and satisfaction.

2. To research the alternatives to the overall quality management framework.

3. Identifying the factors controlling the TQM in businesses.

\section{REVIEW OF LITERATURES}

Munizu, M. (2013) researched aims to test the effects on competitive advantage and corporate success on overall quality control (TQM). Data were obtained by a survey method. The findings of their study show that TQM experience impacts both business success and strategic advantages in both constructive and important ways.

Saffar, N., \& Obeidat, A. (2020) explored the effects on employee efficiency, worked with a moderating share of expertise for the Interior Ministry of Qatar, of Total Quality Management (TQM) activities in their dimensions. TQM includes the focus on our clients, staff engagement, constant development, leadership \& good direction and management of operations. The findings suggest that TQM activities with their measurements have a share of awareness effects on employee efficiency. The findings of their study help to establish and execute various strategic directions, which improve employee efficiency by embracing TQM and spreading a knowledge-sharing culture.

Hoang, D. T., Igel, B., \& Laosirihongthong, T. (2006) explored the connection of Total Quality Management (TQM) with business innovation performance in Vietnam. In their study, they have checked the results of previous research, which found TQM a sequence of works. It shows that the TQM has a positive influence on the innovation of the organisation as a collective of operations. In all of the TQM activities it shows no shift in firm innovation. Leadership and management, process and strategic management and a consistent organisation have been the only constructive impact on its artistic performance.

Sweis, R. J., Al-Mansour, A., Tarawneh, M., \& Al-Dweik, G. (2013) investigated the role of TQM predictors on Saudi healthcare employee empowerment. Results suggest that TM activities have a positive effect on workers as introduced. The study concluded that capacitybased projects, collaboration and coordination are healthier and deeper and that dedicated management, procedures are constantly strengthened and clients are happy.

Karia, N., \& Asaari, M. H. A. H. (2006) analysed the effect on behaviours of workers through Total Quality Management (TQM) activities. The impact of preparation and training on workplace engagement, job satisfaction and organisational involvement are strongly positive. Empowerment and teamwork improve workplace engagement and satisfaction 
considerably. The emphasis on consumers does not encourage engagement or happiness in the workplace.

Prajogo, D. I., \& McDermott, C. M. (2005) examined the relationship between the activity and corporate culture of total quality management (TQM). Conclusions support the pluralistic view in which numerous subsets of TQM activities are described by different cultural groups. The key implication is that organisations must achieve divergent priorities by designing a structure that gives them sufficient flexibility to adapt different types of management (even contrasting ones). As the basis for the report, the test model uses the National Consistency Award Malcolm Baldrige parameters.

\section{TOTAL QUALITY MANAGEMENT}

Total quality management is an organisation's quality management strategy that is founded on the commitment of all of its members and seeks to achieve long term sustainability by pleasing its clients and supporting the members of the organisation and community. Total Quality Control is a coordinated framework to please consumers and suppliers internally and externally by integrating the market climate, improving continuously and breaking through with growth, enhancements and maintenance cycles while evolving corporate cultures.

Total Quality Management refers to the managerial and organisational role to carry out the planning, coordination, direction and control of operations which lead to the determination and execution of the quality standards and standards necessary for goods and services. In particular, the idea of full quality is the notion that perfection and ideal efficiency are very important in all market functions and their allies.

Total quality management philosophy is motivated by the core principles:

"Commitment, Culture, Improvement, Co-Operation, Focus of Customer, Control, CrossFunctional, Cause Analysis, Change, Concept of Teams”.

\subsection{Customer Retention}

The preservation of customers is a number of practises that ensure the long-term management of customers. Most of the businesses reports stated that keeping consumers is much better than buying them. Loyal clients are more likely to invest with you than the average consumer. Data show that increasing retention of customers by $5 \%$ can increase income from $25 \%$ to $95 \%$. The great thing about loyal clients is that they tend, and become your brand ambassador, to share their good experiences.

Some of core customer retention policy has been stated bellow

"Customer feedback Survey, Educate your customer, Good communication with customer, Leverage personalization, Offer fast delivery and easy returns, Find ways to delight your customers consistently, Provide exceptional customer service, Use subscriptions to keep customers coming back"

\subsection{Customer Satisfaction}

Customer satisfaction can be increased, established success can continue or the company can expand well. There are approaches. You should only start offering great customer support, it will be quick to claim. This is too common, though. You should also concentrate on specifics, tasks that more than 'satisfy' your customers.

You want your business to love it so much that they're going to recommend it to everyone. By recognising how rare outstanding customer service is, you can begin to accomplish this purpose. 
Different strategies for better customer satisfaction

"Be credible, Be real Be true, Listen to your customer, Respect your customer, Be transparent, Be consistent, Keep your promises"

\section{RESEARCH METHOD}

A quantitative methodology is used in this analysis. The quantitative approach emphasises theory or concept testing by means of variable metric measurements and by means of statistical tools. A questionnaire method was used for obtaining the data in this study's. The participants were Bhubaneswar, Odisha's customer, 120 retail customers of different showroom were participated in this study

Three main variable i.e Total Quality Management (TQM) practises, retention of customers, customer satisfaction were studied.

\section{RESULT AND DISCUSSION}

\subsection{Validity and Reliability Test}

Table-1 displays the findings of the validity and reliability test. Cronbach's $\alpha$ were centered on the table well above the 0.60 which indicate the data is reliable. It can then be inferred that the method used was correct and Trustworthy.

Table-1

\begin{tabular}{|c|l|c|l|}
\hline SI.No & \multicolumn{1}{|c|}{ Variables/Indicators } & $\begin{array}{c}\text { Cronbach's } \\
\boldsymbol{\alpha}\end{array}$ & \multicolumn{1}{|c|}{ Description } \\
\hline 1 & Total quality management & 0.781 & Reliable \\
\hline 2 & Customer retention & 0.822 & Reliable \\
\hline 3 & Customer satisfaction & 0.845 & Reliable \\
\hline
\end{tabular}

\subsection{Descriptive Statistics}

Three main variable i.e Total Quality Management (TQM) practices, retention of customers, customer satisfaction were studied and the descriptive statistics has been mentioned bellow

Table 2 Descriptive statistics total quality management

\begin{tabular}{|l|c|l|}
\hline \multicolumn{1}{|c|}{ Variables/Indicators } & Mean & \multicolumn{1}{|c|}{ Description } \\
\hline Total quality management & & \\
Commitment & 4.45 & Very High \\
Culture & 3.80 & High \\
Improvement & 4.56 & Very High \\
Co-Operation & 4.78 & Very High \\
Focus of Customer & 4.83 & Very High \\
Control & 3.91 & Very High \\
Cross-Functional & 4.01 & High \\
Cause Analysis & 4.90 & Very High \\
Change & 3.6 & Very High \\
Concept of Teams & 4.23 & High \\
\hline
\end{tabular}


Table 3 Descriptive of customer retention

\begin{tabular}{|l|c|l|}
\hline \multicolumn{1}{|c|}{ Variables/Indicators } & Mean & \multicolumn{1}{|c|}{ Description } \\
\hline Customer retention & & \\
Customer feedback Survey & 4.41 & Very High \\
Educate your customer & 3.82 & High \\
Good communication with customer & 4.33 & Very High \\
Leverage personalization & 4.88 & Very High \\
Offer fast delivery and easy returns & 4.81 & Very High \\
Find ways to delight your customers consistently & 3.95 & Very High \\
Provide exceptional customer service & 4.27 & Very High \\
Use subscriptions to keep customers coming back & 3.67 & High \\
\hline
\end{tabular}

Table 3 Descriptive of Customer satisfaction

\begin{tabular}{|l|l|l|}
\hline \multicolumn{1}{|c|}{ Variables/Indicators } & Mean & \multicolumn{1}{|c|}{ Description } \\
\hline Customer satisfaction & & \\
Be credible & 3.74 & High \\
Be real Be true & 4.55 & Very High \\
Listen to your customer & 4.76 & Very High \\
Respect your customer & 4.31 & Very High \\
Be transparent & 3.97 & High \\
Be consistent & 4.37 & Very High \\
Keep your promises & 3.67 & Very High \\
\hline
\end{tabular}

From the above table it is observed that most of customer reported positively on various aspect of TQM, customer retention and customer satisfaction all result indicates that TQM and customer retention and customer satisfaction are having positive impact on organizational outcome.

\section{CONCLUSION}

The goal of this analysis was to determine the impacts on customer retention and customer satisfaction of TQM activities. From the above research, it was found that TQM activities have a favourable and substantial impact on customer retention and customer satisfaction. Retention of consumers and customer satisfaction have a positive and important impact on corporate results. Via these activities, client engagement and customer loyalty, corporate efficiency is more affected. TQM activities offer the best reason for enhancing corporate efficiency across competitive advantage dimensions such as price or expense, delivery, creativity and time on the market. A better competitive edge will lead to the best results.

\section{REFERENCES}

[1] Munizu, M. (2013). The Impact of total quality management practices towards competitive advantage and organizational performance: Case of fishery industry in South Sulawesi Province of Indonesia. Pakistan Journal of Commerce and Social Sciences (PJCSS), 7(1), 184-197.

[2] Saffar, N., \& Obeidat, A. (2020). The effect of total quality management practices on employee performance: The moderating role of knowledge sharing. Management Science Letters, 10(1), 77-90.

[3] Hoang, D. T., Igel, B., \& Laosirihongthong, T. (2006). The impact of total quality management on innovation. International journal of quality \& reliability management. 
Impact of Total Quality Management Practice on Customer Retention and Satisfaction

[4] Sweis, R. J., Al-Mansour, A., Tarawneh, M., \& Al-Dweik, G. (2013). The impact of total quality management practices on employee empowerment in the healthcare sector in Saudi Arabia: a study of King Khalid Hospital. International Journal of Productivity and Quality Management, 12(3), 271-286.

[5] Karia, N., \& Asaari, M. H. A. H. (2006). The effects of total quality management practices on employees' work-related attitudes. The TQM magazine.

[6] Prajogo, D. I., \& McDermott, C. M. (2005). The relationship between total quality management practices and organizational culture. International Journal of Operations \& Production Management. 